MINERALOGIA, 48, No 1-4: 23-38 (2017)

DE DE GRUYTER OPEN

DOI: 10.1515/mipo-2017-0009

www.Mineralogia.pl

MineRALOGICAL SOCIETY OF POLAND

Polskie TOWARZYSTWO MINERALOGICZNE

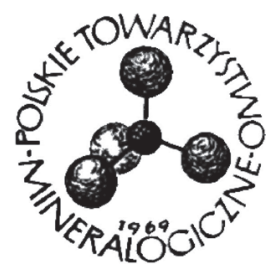

Original paper

\title{
Bentonite from the Central Slovakia Volcanic Field - A prospective raw material for Polish industry
}

\author{
Katarzyna Górniak ${ }^{1 *}$, Tadeusz Szydłak ${ }^{1}$, Adam Gaweł ${ }^{1}$, Agnieszka Klimek ${ }^{1}$, Anna \\ Tomczyk $^{1}$, Jerzy Motyka ${ }^{2}$, Krzysztof Bahranowski $^{1}$ \\ ${ }^{1}$ AGH - University of Science and Technology, Faculty of Geology, Geophysics and Environmental Protection, \\ Al. A. Mickiewicza 30, 30-059 Kraków, Poland \\ ${ }^{2}$ CERTECH, ul. Fabryczna 36, 33-132 Niedomice, Poland \\ * Corresponding author \\ e-mail gorniak@agh.edu.pl
}

Received: July 7, 2017

Received in revised form: August 25, 2017

Accepted: August 26, 2017

Available online: September 30, 2017

\begin{abstract}
This paper summarizes information about recently worked bentonite deposits in Slovakia and presents the results of studies on bentonite from the Central Slovakia Volcanic Field (CSVF). The authors compared the mineralogy of commercial bentonites exploited in the Stara Kremnička (Jelšový potok), Kopernica, and Hliník nad Hronom deposits. X-ray diffraction (XRD), chemical analyses and microscopy showed that the main component is montmorillonite (37-88\%), followed by opal C/CT (5-25\%), clinoptilolite (up to 15\%), feldspars (3-12\%), quartz (up to $8 \%$ ), biotite (2-5\%), and kaolinite (up to $2 \%$ ). The microscopic imaging provided information valuable for the technological assessment of bentonites, particularly the evaluation of mineralogy determined by XRD. The low variability of the mineral composition of commercial bentonites exploited in the western CSVF, together with the significant reserves and localization of deposits close to the Polish-Slovak state border prove that this raw material deserves more attention from Polish industry.
\end{abstract}

Key-words: commercial bentonite, Central Slovakia Volcanic Field, petrography, smectite, microscopic imaging

\section{Introduction}

Poland only has low quality bentonite resources, which represent the weathering products of some Lower Silesian basalts. In contrast to Poland, Slovakia is rich in bentonite deposits (Table 1). Most of these occur in Central Slovakia, in the vicinity of Banská 
Bystrica (Fig. 1, Table 2). The remaining localities are clustered in Eastern Slovakia, in the vicinity of Košice (Fig. 1). For a dozen year, the number of assessed deposits and the production of bentonites in Slovakia have been systematically growing (Table 1). Bentonites from Slovakia thus appear to be an interesting raw material for Polish industry. An example of this is the company CERTECH, which is based in Niedomice near Tarnów and imports Slovak bentonites for manufacturing a wide range of goods (for more details, visit www.certech.com). It should be noted that several studies have paid attention to the possible application of Slovak bentonites in Polish industry, such as Wyszomirski and Lewicka (2005), Lewicka and Wyszomirski (2008) and Panna et al. (2012).

TABLE 1

Assessed bentonite deposits in Slovakia: number, reserves and production in the 2001-2013 period (source: Slovak Mineral Yearbook, 2014).

\begin{tabular}{|c|c|c|c|c|}
\hline \multirow{2}{*}{ Year } & \multicolumn{2}{|c|}{ Number of deposits } & \multirow{2}{*}{ Reserves [kt] } & \multirow{2}{*}{ Mining output [kt] } \\
\hline & total & exploited & & \\
\hline 2001 & 19 & 2 & 41,738 & 80 \\
\hline 2002 & 21 & 5 & 42,697 & 84 \\
\hline 2003 & 21 & 4 & 42,573 & 98 \\
\hline 2004 & 21 & 5 & 41,726 & 98 \\
\hline 2005 & 23 & 4 & 42,351 & 97 \\
\hline 2006 & 23 & 6 & 42,192 & 136 \\
\hline 2007 & 23 & 8 & 42,462 & 149 \\
\hline 2008 & 23 & 9 & 42,179 & 145 \\
\hline 2009 & 22 & 7 & 42,035 & 109 \\
\hline 2010 & 23 & 7 & 47,906 & 153 \\
\hline 2011 & 29 & 11 & 49,109 & 213 \\
\hline 2012 & 29 & 10 & 48,920 & 177 \\
\hline 2013 & 30 & 11 & 53,686 & 184 \\
\hline
\end{tabular}

The mineral composition and the origin of bentonites from Slovakia were studied by Kraus et al. (1982, 1989, 1994), Čičel et al. (1992), Šamajová et al. (1992), Šucha et al. (1996); Andrejkovičová et al. (2006) and Uhlík et al. (2012), among others. Moreover, information about the mineral composition of commercial Slovak bentonites can be found in Panna et al. (2012), Deliová et al. (2015) and Górniak et al. (2016, 2017). Recently, the growing interest of Slovak scientists in local bentonite resources has been stimulated by the attempts to use this raw material as a component in the barriers protecting nuclear waste repositories (see e.g. Andrejkovičová et al. 2008; Adamcová et al. 2009, 2014; Galamboš et al. 2011; Striček et al. 2011). 


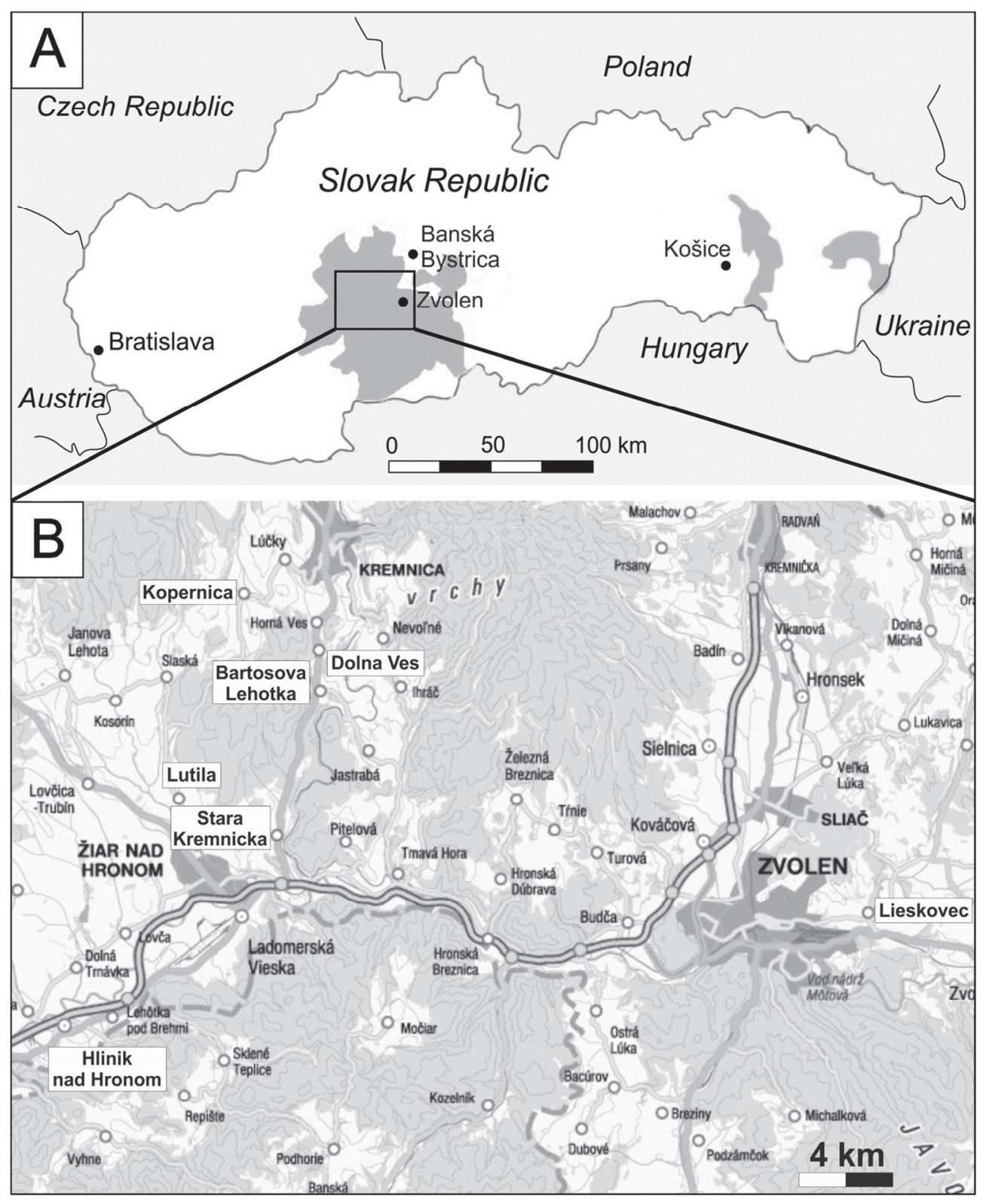

Fig. 1. A - Regions of bentonite deposits in Slovakia; B - Localization of bentonite deposits in the CSVF (mentioned in Tab. 1).

This paper is devoted to bentonites from the Central Slovakia region located in the Neogene volcanics, known in the literature as the Central Slovakia Volcanic Field (CSVF). This is one of the largest areas in Europe featuring the occurrence of bentonite deposits (Šucha, Kraus 1999). Considering the available literature, one can conclude that Slovakian bentonites from the CSVF are less variable in mineral composition than the famous Greek 
and Turkish industrial deposits (see e.g. Christidis, Dunham 1993; Christidis, Dunham 1997; Arslan et al. 2010; Koutsopoulou et al. 2016). Moreover, they seem to be quite similar to commercially appreciated bentonites from Algeria (see Arbaoui, Boucherit 2014).

The authors aim to summarize the current state of knowledge about Slovakian bentonites from the CSVF, based upon the literature and their own studies. Special attention was paid to the compositional variability of commercial bentonites worked out in the last dozen year from the largest deposits located in the western part of the CSVF. Moreover, the reader has an opportunity to recognize how much the progress in modern analytical techniques enables researchers to integrate the standard evaluation methods of mineral composition with Field Emission Scanning Electron Microscopy (FESEM) imaging (see Górniak et al. 2016; Górniak et al. 2017). This new methodology improves our knowledge, which results in better understanding of bentonites' technological properties, and consequently leads to more efficient utilization of this valuable raw material.

\section{Location and geological background}

The CSVF occupies a vast area south-west from Banská Bystrica and extends up to the Slovak-Hungarian state border (Fig. 1A). This is the largest (over 5,000 $\mathrm{km}^{2}$ ) post-orogenic volcanic structure in the Western Carpathians. It includes a dozen Neogene stratovolcanoes, from which the largest is Štiavnica Volcano (see e.g. Konečny et al. 2001). This volcanic rock with bentonite deposits is known as the Jastrabá Formation (Konečny et al. 2001). Bentonites were formed in the Late Miocene as a result of the alteration of rhyolitic or, less commonly, older andesitic volcanics in a lacustrine environment (see e.g. Kraus et al. 1982; Kraus et al. 1989; Kraus et al. 1994; Šamajová et al. 1992).

\section{Bentonite deposits in the CSVF}

According to the Record of Mining Areas (Evidencia Dobyvacich Priestorov) (2016), there are 15 bentonite deposits recently under exploitation located in seven villages (Fig. 1B, Table 2). The vast majority of these deposits occur in the western part of the CSVF.

In the western part of the CSVF there are thirteen deposits formed by the alteration of rhyolitic volcanics (see e.g. Kraus et al. 1982; Kraus et al. 1989; Kraus et al. 1994; Šamajová et al. 1992). The largest and best-known is the Jelšový potok I deposit in the village of Stara Kremnička. Bentonites from this locality have been studied for decades by Slovak geologists (see e.g. Kraus et al. 1982; Kraus et al. 1989; Čičel et al. 1992; Madejová et al. 1992 and references therein). In recent years, still more attention has been paid to deposits located around the village of Kopernica, where four mines are working: Kopernica II, III, IV and V (Table 2). Bentonites from the Kopernica were studied by Striček et al. (2006), Adamcová et al. (2009), Adamcová et al. (2014), Galamboš et al. (2011), Panna et al. (2012), Deliová et al. (2015) and Górniak et al. (2016), among others. South from these deposits, close to the village of Hliník nad Hronom, two additional bentonite deposits are currently mined: Hliník nad Hronom I and II. These bentonites were studied by Uhlík et al. (2012) and Górniak et al. (2017). Finally, three new important deposits are located between 
the villages of Stara Kremnička and Kopernica (Fig. 1B, Table 2): Lutila, Bartošova Lehôtka and Dolná Ves.

Bentonite deposits in the CSVF (source: Record of Mining Areas, 2016).

\begin{tabular}{lll}
\hline Location & Deposit & Mining company \\
\hline Bartošova Lehôtka & Bartošova Lehôtka II & REGOS s.r.o., Bratislava \\
\hline Dolna Ves & Dolna Ves & REGOS s.r.o., Bratislava \\
\hline Hlinik nad Hronom & Hlinik nad Hronom I & GEMERSKÁ NERUDNÁ SPOLEČNOSŤ a.s. \\
& & Hnúšta \\
& Hlinik nad Hronom II & CONCEPT MINERALS s.r.o., Kopernica \\
\hline Kopernica & Kopernica II & KOPERKOMIN s.r.o., Kopernica \\
& Kopernica III & BENOX s.r.o., Banská Bystrica \\
& Kopernica IV & BENTOKOP s.r.o., Kopernica \\
& Kopernica V & REGOS s.r.o., Bratislava \\
\hline Lieskovec & Lieskovec & ENVIGEO a.s., Banská Bystrica \\
\hline Lutila & Lutila & ENERGOGAZ a.s., Košice \\
& Lutila I & REGOS s.r.o., Bratislava \\
& Lutila II & REGOS s.r.o., Bratislava \\
\hline Stara Kremnička & Stara Kremnička I & KREMNICKÁ Banská Spoločnost’ s.r.o, Kremnica \\
& (Jelšový potok I) & \\
& Stara Kremnička II & ENERGOGAZ a.s., Košice \\
& Stara Kremnička III & REGOS s.r.o., Bratislava \\
\hline
\end{tabular}

In the eastern CSVF, in the vicinity of the town of Zvolen, the Lieskovec bentonite deposit was discovered (Fig. 1B). This bentonite is a product of alterations of andesite volcanic rock (Kraus et al. 1989). Thus, in contrast to the bentonites from the western CSVF, this one is Fe-rich due to the domination of Fe-montomorillonite in the mineral composition (Šucha et al. 1996; Andrejkovičová et al. 2006).

\section{Materials}

The study was based upon six samples of commercial bentonite originating from the four largest and best-recognized deposits located in the western CSVF: Kopernica III, Kopernica IV, Hliník nad Hronom I and Stara Kremnička I (Jelšový potok I) (Fig. 1B, Tab. 2).

Bentonites from the Kopernica III, Kopernica IV and Hliník nad Hronom I deposits are currently imported by CERTECH. The samples represent portions of commercial bentonite transported to Poland in 2013 and collected from the company's storage in accordance with the routine procedure applied by CERTECH for the quality control of the raw material. In the Kopernica III deposit, where the selective mining technique is applied, two samples were collected: Kop-3, which represents the main product of the mine; and Kop-A, which is 
a bentonite variety richest in smectite. Both the sampling procedures and some of the results of studies on commercial bentonites from the Kopernica III and IV, and Hliník nad Hronom deposits were presented in Górniak et al. (2016) and Górniak et al. (2017), respectively. Bentonite from the Stara Kremnička I (Jelšový potok I) deposit was represented by two samples collected from the mine storage in 2006 (JP-1 sample) and in 2016 (JP-2 sample).

\section{Methods}

Microscopic observations were made with an Olympus BX 51 polarizing microscope on standard $(0.03 \mathrm{~mm})$ thin sections impregnated with epoxy resin.

For the FESEM, a FEI Quanta 200 FEG instrument was used, equipped with secondary electron (SE) and back-scattered electron (BSE) detectors, and an energy dispersive spectrometer (EDS). Both the polished and thin sections impregnated with epoxy resin and the fresh, carbon-coated rock fractures were subjected to observations. The BSE imaging of uncoated polished thin sections was conducted at $20 \mathrm{kV}$ using the low-vacuum mode.

The X-ray diffraction (XRD) powder patterns were obtained with a Rigaku SmartLab diffractometer under the following analytical parameters: graphite-monochromatized $\mathrm{CuK}_{\alpha}$ radiation, operating voltage $45 \mathrm{kV}$, current $200 \mathrm{~mA}$, step $0.05^{\circ} 2 \theta$ at the counting time 1 $\mathrm{sec} / \mathrm{step}$ for the qualitative phase analysis and step $0.02^{\circ} 2 \theta$ at the counting time $2 \mathrm{sec} / \mathrm{step}$ for the quantitative analysis.

In order to identify the clay minerals, the suspensions of $<2 \mu \mathrm{m}$ grain size fraction were spread on glass slides and allowed to dry in the ambient atmosphere. The X-ray patterns were recorded for sets of oriented samples: air-dried and solvated with ethylene glycol.

For quantitative $\mathrm{X}$-ray analyses, $10 \mathrm{wt} . \% \mathrm{ZnO}$ was added to the samples as an internal standard and the mixture was homogenized in a McCrone mill. From such a material, the "side loading" samples were prepared to assure the best crystallite disorientation. The analysis was carried out with the standardless Rietveld method using SiroQuant software.

Chemical analyses of the bulk samples were conducted with the X-ray fluorescence technique (XRF). Samples for the analyses were prepared using the $\mathrm{LiB}_{4} \mathrm{O}_{7}$ fusion method. The resulting beads were analyzed in a ZSX Primus II (Rigaku) spectrometer using calibration graphs prepared from certified reference materials.

\section{Petrography of commercial bentonites from the western CSVF}

All the studied bentonite samples revealed light-grey colors with common yellowish shade. In that groundmass, pyroclastic grains approximately $1 \mathrm{~mm}$ in diameter were visible, comprising of fresh, black biotite and less common feldspars, and quartz. Moreover, in the bentonites from the Hliník nad Hronom I and Kopernica IV deposits, lithic fragments of volcanic rocks with a porphyry structure were observed, usually up to several millimeters (rarely up to $20 \mathrm{~mm}$ ) across. 


\section{1. $X R D$}

The XRD analyses of the natural samples indicate that apart from smectite, quartz, feldspars, micas and opal $\mathrm{C} / \mathrm{CT}$ are also present, together with less common clinoptilolite and rare kaolinite (Fig. 2). The content of smectite varies from 37 to $88 \mathrm{wt} . \%$ (Table 3). The admixtures important from a technological point of view are opal C/CT (from 5 to $25 \mathrm{wt} . \%$ ) and clinoptilolite (up to $15 \mathrm{wt} . \%$ ). The $\mathrm{d}_{001}$ value of the basal smectite peak for all analyzed samples falls into the 14.7-15.2 $\AA$ range, which suggests the presence of divalent interlayer cations (mainly $\mathrm{Ca}^{2+}$ ) in the smectite.

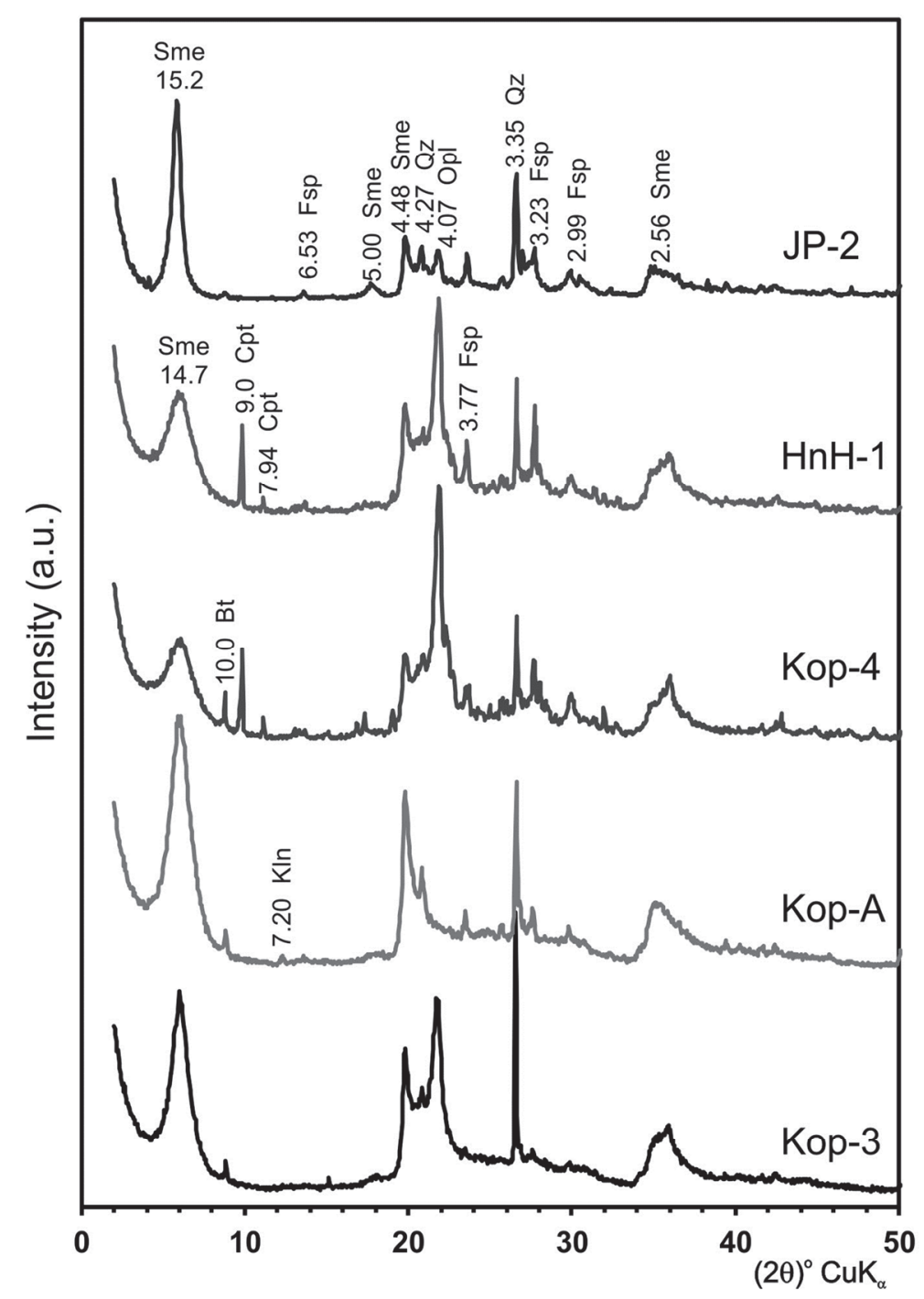

Fig. 2. XRD patterns of bulk rock samples. Explanations: Bt - biotite, $\mathrm{Cpt}$ - clinoptilolite, Fsp feldspars, Opl - opal C/CT, Qz - quartz, Sme - smectite, $d_{\mathrm{hkl}}$ in $\AA$. 
Mineral composition of selected commercial bentonites from the CSVF [wt.\%].

\begin{tabular}{|c|c|c|c|c|c|c|}
\hline \multicolumn{2}{|c|}{ Location } & \multicolumn{3}{|c|}{ Kopernica } & $\begin{array}{l}\text { Hliník nad } \\
\text { Hronom }\end{array}$ & Stara Kremnička \\
\hline \multicolumn{2}{|c|}{ Deposit } & \multicolumn{2}{|c|}{ Kopernica III } & $\begin{array}{l}\text { Kopernica } \\
\text { IV }\end{array}$ & $\begin{array}{l}\text { Hliník nad } \\
\text { Hronom I }\end{array}$ & $\begin{array}{l}\text { Stara Kremnička I } \\
\text { (Jelšový potok I) }\end{array}$ \\
\hline \multicolumn{2}{|c|}{ Sample } & Kop-3 & Kop-A & Kop-4 & $\mathrm{HnH}-1$ & JP-2 \\
\hline \multirow{7}{*}{ 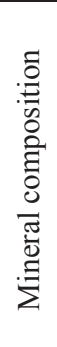 } & Smectite & 69 & 88 & 37 & 47 & 85 \\
\hline & Quartz & 5 & b.d. & 8 & 3 & 2 \\
\hline & Biotite & 5 & 2 & 3 & 3 & 3 \\
\hline & Opal C/CT & 18 & 5 & 25 & 20 & 5 \\
\hline & Feldspars & 3 & 3 & 12 & 12 & 5 \\
\hline & Clinoptilolite & b.d. & b.d. & 15 & 15 & b.d. \\
\hline & Kaolinite & b.d. & 2 & b.d. & b.d. & b.d. \\
\hline
\end{tabular}

Source of data is from Górniak et al. 2016 (Kopernica) and Górniak et al. 2017 (Hliník nad Hronom) b.d. - below detection limit.

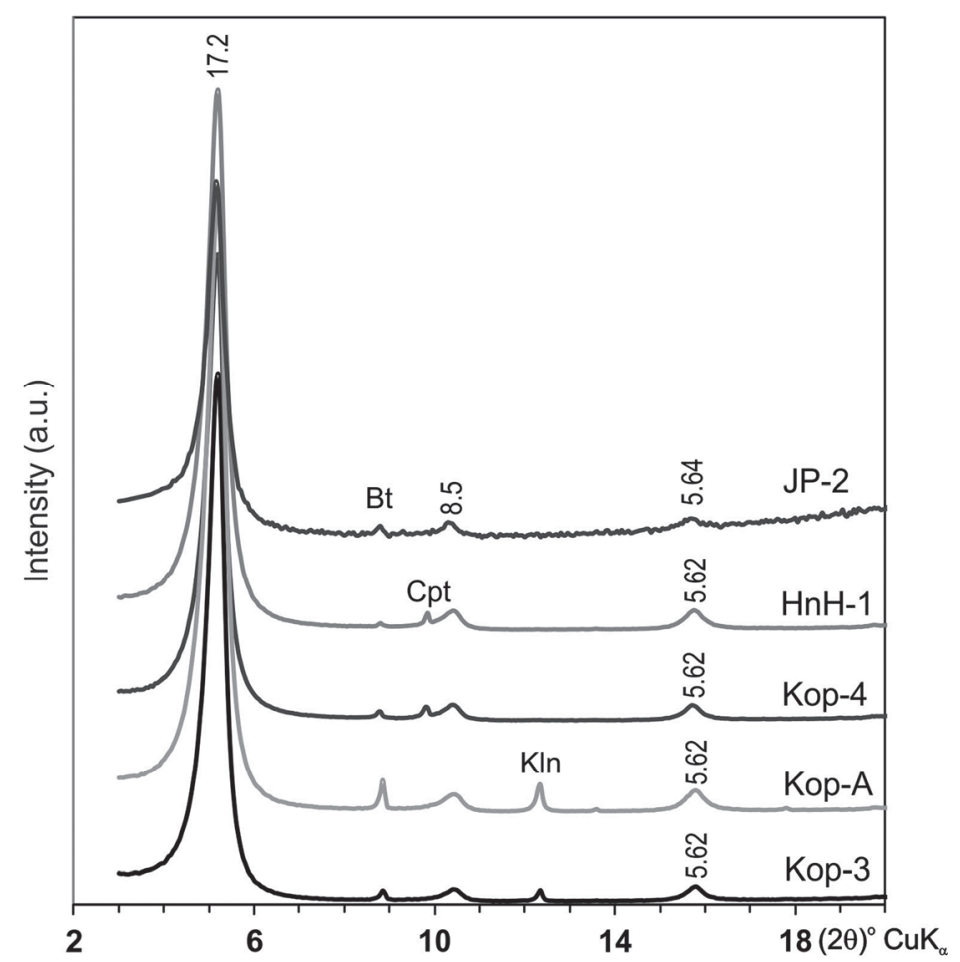

Fig. 3. XRD patterns of oriented, glycolated samples $(<2 \mu \mathrm{m}$ grain size fraction). Explanations: smectite $-\mathrm{d}_{\mathrm{hkl}}$ in $\AA, \mathrm{Bt}$ - biotite, $\mathrm{Cpt}$ - clinoptilolite, $\mathrm{Kln}$ - kaolinite. 
The XRD analyses of the $<2 \mu \mathrm{m}$ fraction separated from the bentonite samples demonstrate the presence of $100 \%$ of swelling layers, as revealed by the value of $\mathrm{d}_{003}=$ 5.62-5.64 $\AA$ peak recorded in the patterns of oriented samples solvated with ethylene glycol (see Reynolds, Hower 1970) (Fig. 3). Earlier studies on smectite from bentonites originating from the Kopernica and the Hliník nad Hronom mines identified montmorillonite (Górniak et al. 2016; Górniak et al. 2017).

\subsection{Optical microscopy}

Under the optical microscope, both the pyroclastic grains (up to $1 \mathrm{~mm}$ across) and lithic fragments (usually from 0.5 to several millimeters across) were observed, randomly disseminated in the clay groundmass (Fig. 4A, B) replacing the glass. The initial, porous structure of the glass is usually well preserved.

The pyroclastic grains are represented by quartz, plagioclases and biotite (Fig. 4A). The quartz forms wedge-shaped crystal chips or less common, euhedral, often rounded crystals. Subhedral, usually rounded plagioclases show polysynthetic twinnigs and zonality, and are generally well preserved. The potassium feldspars hosted in the bentonite from the Kopernica III deposit, the richest in smectite (Kop-A sample), are almost completely replaced by kaolinite. Biotite, usually euhedral, can be fresh or variously replaced by iron and titanium minerals. The cleavage planes and the cracks are filled with smectite.

The lithic fragments are particularly common in the bentonite from the Hliník nad Hronom and the Kopernica IV deposits. These fragments of volcanics show a porphyry structure (Fig. 4B). The initial glassy groundmass is replaced by clay minerals. Phenocrysts of euhedral feldspars are variously altered. Our studies revealed that in the bentonites from the Hliník nad Hronom deposit the phenocrysts are mostly plagioclases (Górniak et al. 2017), whereas in the bentonites from the Kopernica deposit, plagioclase, biotite and quartz phenocrysts occur.

Clinoptilolite forms relatively large, tabular crystals up to $0.2 \mathrm{~mm}$ in diameter (Fig. 4C), which locally fill the vacuoles and open spaces left after the dissolved volcanic glass, and replace that glass.

\subsection{FESEM}

The montmorillonite observed in the bentonite from the western CSVF (deposits in the Kopernica, Stara Kremnička and Hliník nad Hronom areas) is a product of the alteration of volcanic (mostly pumice) glass. In most samples, the glass is completely replaced by montmorillonite, except for the bentonite from the Stara Kremnička I (Jelšový potok I) deposit, where glass relics were encountered (Fig. 4D). The size of the montmorillonite pseudomorphs after the glass fragments varies from several to some hundreds of micrometers. Microscopic examinations showed that some smectitic pseudomorphs can be cemented by microcrystals of autigenic K-feldspar (Fig. 4E) and by lepishperes of opal $\mathrm{C} / \mathrm{CT}$, up to $5 \mu \mathrm{m}$ in diameter (Fig. $4 \mathrm{~F}$ ). 

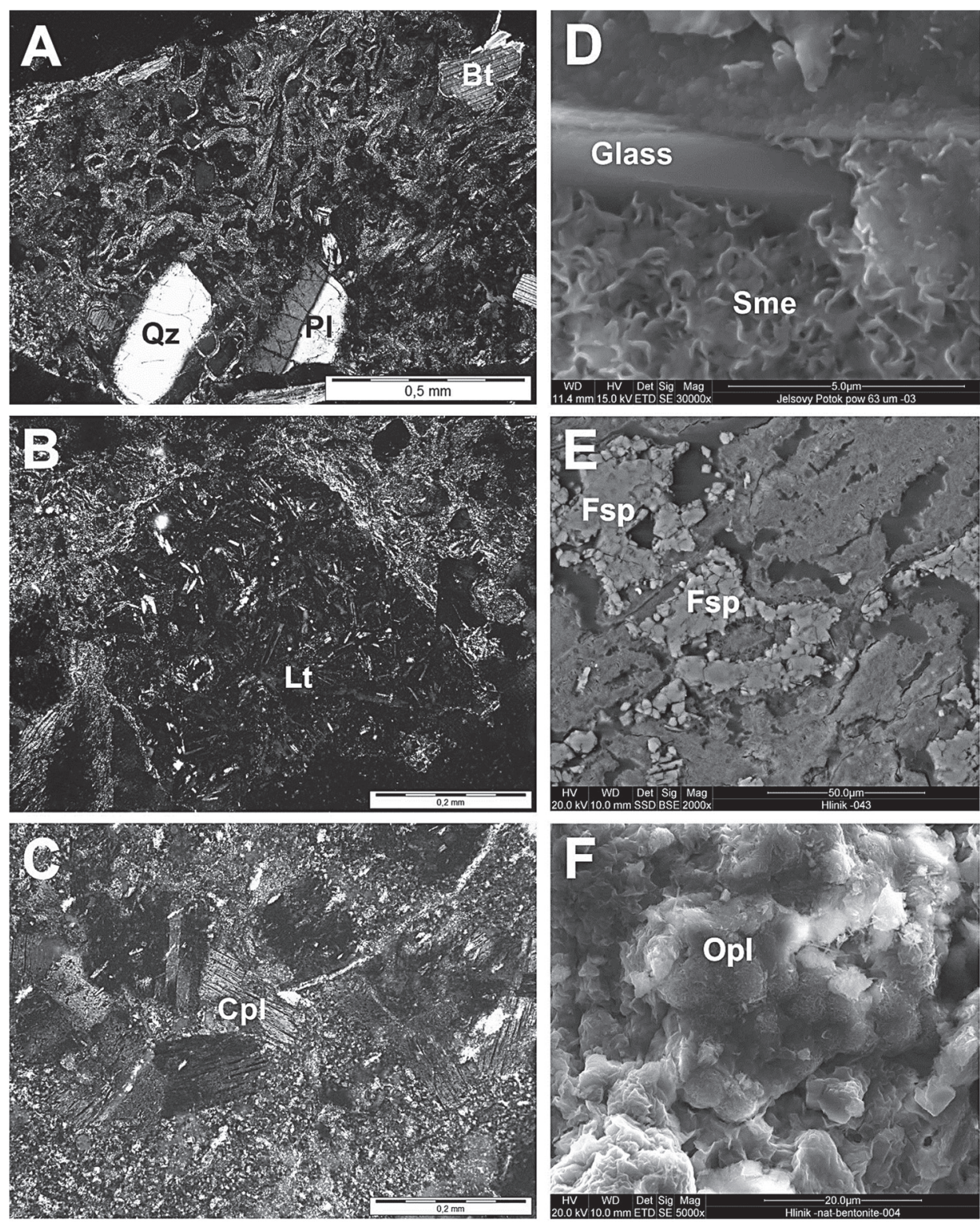

Fig. 4. Optical microscopy (A-C) and FESEM images (D-F) of non-clay components of bentonites from the CSVF: A - crystal of quartz $(\mathrm{Qz})$, plagioclase $(\mathrm{Pl})$ and biotite $(\mathrm{Bt})$ disseminated in the groundmass composed of smectite-replaced pumice fragments; crossed polars, sample Kop-4. $\mathrm{B}$ - lithic fragment (Lt) surrounded by smectite-replaced pumice shreds; crossed polars, sample HnH1. C - large crystals of clinoptilolite $(\mathrm{Cpl})$ in altered pumice fragment; plane polarized light, sample HnH-1. D - remnants of volcanic glass fragments altered to smectite (Sme); fractured surface, $>63 \mu \mathrm{m}$ grain size fraction, sample JP-1. E - smectite-replaced pumice fragments cemented by micrometer-size authigenic K-feldspar crystals (Fsp); polished thin section, sample HnH-1. $\mathrm{F}$ - lepispheres of opaline silica; fractured surface, sample $\mathrm{HnH}-1$. 

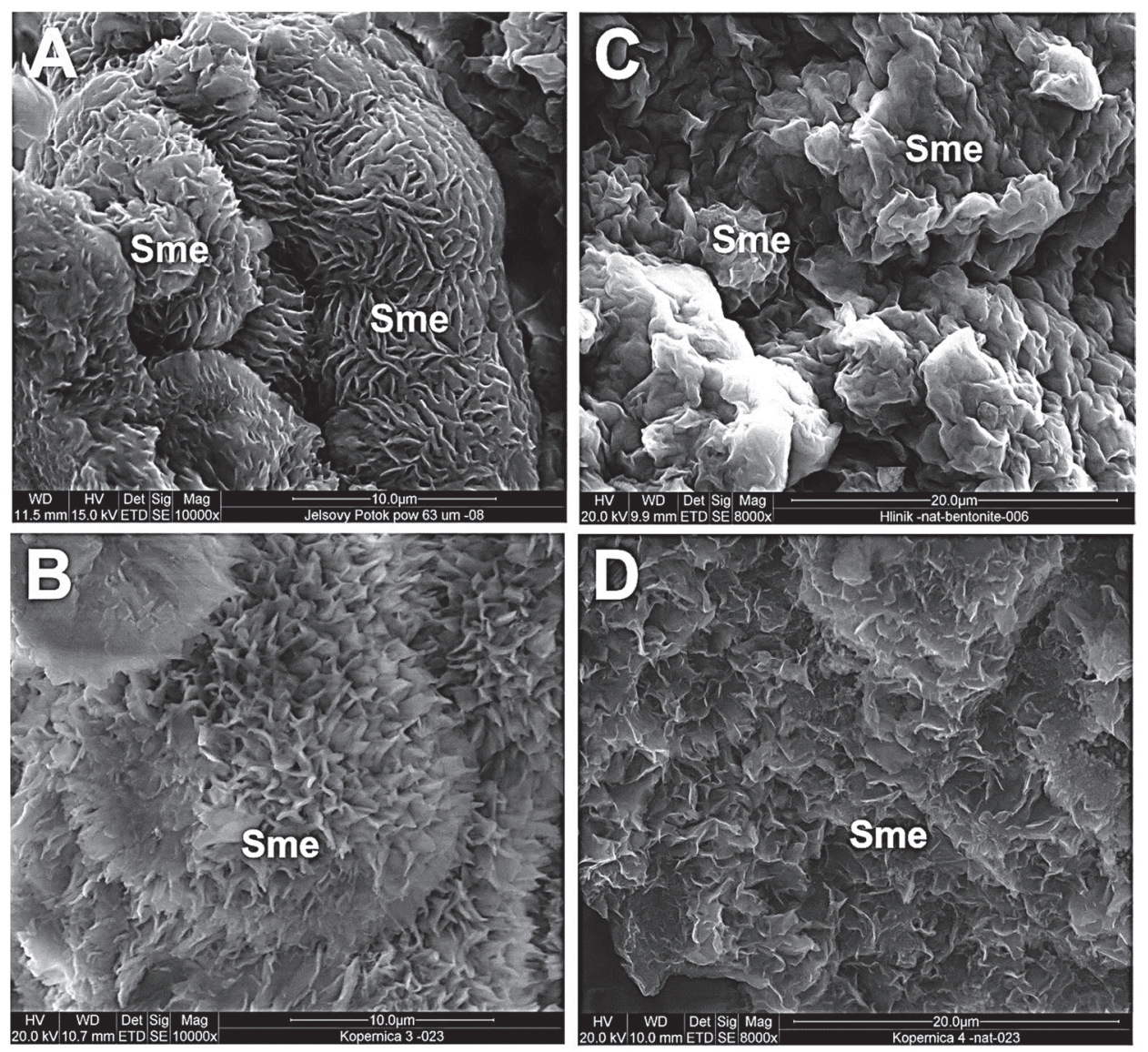

Fig. 5. FESEM images (fractured surfaces) of rosette-like smectite aggregates (Sme) in bentonites from the CSVF. Samples: (A) JP-1, (B) Kop-3, (C) HnH-1 and (D) Kop-4.

In all the studied bentonite samples, the montmorillonite flakes form rosette-like aggregates of diameters up to a dozen micrometers (Fig. 5). Single rosettes may locally form at the surface of glass shards and may coalesce into concentric films at the final stage of glass replacement.

\subsection{XRF}

The content of $\mathrm{SiO}_{2}$ and $\mathrm{Al}_{2} \mathrm{O}_{3}$ in the analyzed bentonites varies from $66-73$ wt.\% and $17-25 \mathrm{wt} . \%$, respectively. The content of $\mathrm{MgO}$ varies from 1.7 to $3.1 \mathrm{wt} . \%$ and correlates well with the content of montmorillonite. The content of $\mathrm{CaO}$ is similar in all the analyzed samples and somewhat exceeds $2 \mathrm{wt} . \%$. The alkali content is low: $<1 \mathrm{wt} . \%$ of $\mathrm{Na}_{2} \mathrm{O}$ and $2 \mathrm{wt} . \%$ of $\mathrm{K}_{2} \mathrm{O}$. The Fe content recalculated to $\mathrm{Fe}_{2} \mathrm{O}_{3}$ is below $3 \mathrm{wt} . \%$ in the bentonite from the Kopernica III deposit and close to $4 \mathrm{wt} . \%$ in those from the Kopernica IV and the Hliník nad Hronom deposits (Table 4). 
Chemical composition of selected commercial bentonites from the CSVF [wt.\%].

\begin{tabular}{|c|c|c|c|c|c|c|}
\hline \multicolumn{2}{|c|}{ Location } & \multicolumn{3}{|c|}{ Kopernica } & $\begin{array}{l}\text { Hliník nad } \\
\text { Hronom }\end{array}$ & Stara Kremnička \\
\hline \multicolumn{2}{|c|}{ Deposit } & \multicolumn{2}{|c|}{ Kopernica III } & $\begin{array}{l}\text { Kopernica } \\
\text { IV }\end{array}$ & $\begin{array}{l}\text { Hliník nad } \\
\text { Hronom I }\end{array}$ & $\begin{array}{l}\text { Stara Kremnička I } \\
\text { (Jelšový potok I) }\end{array}$ \\
\hline Sam & & Kop-3 & Kop-A & Kop-4 & $\mathrm{HnH}-1$ & average \\
\hline \multirow{7}{*}{ 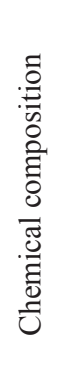 } & $\mathrm{SiO}_{2}$ & 69.4 & 66.0 & 72.9 & 70.8 & $57-61$ \\
\hline & $\mathrm{Al}_{2} \mathrm{O}_{3}$ & 22.1 & 24.6 & 16.6 & 17.5 & $18-21$ \\
\hline & $\mathrm{Fe}_{2} \mathrm{O}_{3}$ & 2.5 & 2.8 & 3.4 & 3.7 & $\begin{array}{l}\mathrm{Fe}_{2} \mathrm{O}_{3}-2-5 \\
\mathrm{FeO}-0,1-0,5\end{array}$ \\
\hline & $\mathrm{MgO}$ & 2.8 & 3.1 & 1.7 & 2.4 & $3.0-3.5$ \\
\hline & $\mathrm{CaO}$ & 2.0 & 2.1 & 2.4 & 2.6 & $1.9-2.6$ \\
\hline & $\mathrm{Na}_{2} \mathrm{O}$ & 0.1 & 0.2 & 0.9 & 0.5 & $0.2-0.7$ \\
\hline & $\mathrm{K}_{2} \mathrm{O}$ & 0.8 & 1.1 & 1.7 & 1.6 & $0.4-1.0$ \\
\hline
\end{tabular}

Source of data is from Górniak et al. 2016 (Kopernica), Górniak et al. 2017 (Hliník nad Hronom), and Šucha, Kraus 1999 (Stara Kremnička)

\section{Discussion}

\subsection{Variability of commercial bentonites from the western CSVF}

The available literature (Kraus et al. 1982; Kraus et al. 1989; Kraus et al. 1994; Šamajová et al. 1992; Šucha, Kraus 1999; Panna et al. 2012; Uhlík et al. 2012) and our own studies (Górniak et al. 2016; Górniak et al. 2017) allow us to suggest that bentonites mined in the western CSVF, between Kopernica and Hliník nad Hronom, reveal relatively stable and simple mineral and chemical compositions. The main mineral is smectite, accompanied by variable amounts of opal $\mathrm{C} / \mathrm{CT}$ and clinoptilolite. This smectite is, in fact, montmorillonite. Its structural formula provided by Čičel et al. (1992) for samples from the Stara Kremnička I area (Jelšový potok I deposit) is similar to that obtained by Górniak et al. (2016) for the bentonite from Kopernica. Higher content of admixtures usually appears in the bottom parts of deposits (Kraus et al. 1994). The admixtures of opal C/CT and clinoptilolite do not affect the quality of bentonites, and in some cases can be an advantage of this raw material (Górniak et al. 2017).

The stability of the mineral and chemical compositions of commercial bentonites is a favorable property from a technological point of view. Bentonites exploited in the CSVF reveal less diversified lithologies and nature of smectites, even if their geological history is similarly complicated as that of other parts of Europe (see e.g. Christidis, Dunham 1993, 1997; Arslan et al. 2010; Koutsopoulou et al. 2016). The homogeneity of the mineral composition of bentonites from the CSVF was explained by Kraus et al. (1994). According to their model, the precursors of bentonites were rhyolitic volcanoclastics produced during the latest eruptive episode in that region. These rocks were then altered into bentonites 
during the diagenetic processes. Hence, the homogenic composition of bentonites from the western CSVF should be related to the homogeneity of volcanic precursors, which covered relatively vast areas and which were subjected to diagenetic transformations under similar conditions.

\subsection{Mineral composition and quality of commercial bentonites}

The technological quality of bentonites from the western CSVF depends mostly on the content of smectite, if this principal assessment criterion is accepted. It is valid also for the potential utilization of bentonites for the construction of barriers in radioactive waste repositories (see e.g. Andrejkovičová et al. 2008; Adamcová et al. 2009; Adamcová et al. 2014; Galamboš et al. 2011). However, analysis of the available literature also reveals that bentonites rich in opal $\mathrm{C} / \mathrm{CT}$ and zeolites can be considered as raw materials of mixed physical and chemical properties. Such raw materials can be interesting for new "unconventional" technologies such as those applied in some branches of the chemical industry (e.g. Sohling et al. 2009).

An important property of Slovakian bentonites featured by some authors (e.g., Uhlík et al. 2012; Górniak et al. 2016; Górniak et al. 2017) is their relatively weak interaction with water. This is a crucial technological parameter of bentonite raw materials (e.g. Christidis 2013; Harvey, Lagaly 2013). Our observations demonstrate that smectite flakes are to a various extent cemented by opal $\mathrm{C} / \mathrm{CT}$ and by microcrystals of K-feldspar, which may reduce the response of bentonite to water. The purification of bentonites from the CSVF can be facilitated by the initial, gentle grinding of raw materials. This can facilitate more effective sodium activation.

\subsection{CSVF as a prospective region for bentonite raw material}

The CSVF seems to be a very prospective source of bentonite due to the significant reserves and the homogeneity of the raw material. For Polish customers, the additional advantage is the short distance from the mines to the Polish-Slovak state border. In recent years, the production of Slovak bentonites for local usage and for export has been systematically growing. Moreover, the number of newly assessed and developed deposits has increased, particularly in the western CSVF (Table 1,2). Bentonites from the eastern CSVF differ from those mined in the western part due to the presence of Fe-smectite. This results from different precursors, which are the andesitic pyroclasts, and from different weathering conditions (e.g. Kraus et al. 1982; Kraus et al. 1989; Kraus et al.1994; Šamajová et al. 1992). Hence, the technological properties of these bentonites are somewhat contrasting (e.g. Šucha et al. 1996; Andrejkovičová et al. 2006) in comparison with those from the western CSVF. Up to now, only one deposit of Fe-rich bentonite (Lieskovec) is under exploitation in the eastern CSVF (Fig. 1). Recently, raw bentonite has been worked and supplied mostly by Slovak companies (Table 1), sometimes supported by foreign capital from Austria, the Czech Republic and Poland. 


\section{Conclusions}

Our studies reveal that bentonites exploited in the CSVF since ca. 1980 have stable mineral composition. The main component is montmorillonite, with $\mathrm{Ca}^{+2}$ interlayer cations. Both the opal $\mathrm{C} / \mathrm{CT}$ and clinoptilolite are present in various amounts, even up to $25 \mathrm{wt} . \%$.

Bentonites with higher contents of opal $\mathrm{C} / \mathrm{CT}$ and clinoptilolite can be utilized in various industries traditionally applying siliceous raw materials and zeolites.

Our results strongly support the opinion that the proper evaluation of the technological properties of bentonite can be accomplished by the integration of standard methodology (analyses of smectite content and determination of mineral composition with XRD) and microscopic imaging techniques, followed by analysis of the relationships between particular minerals.

The bentonites from the CSVF are very useful for Polish customers due to the high quality and homogeneity of the raw material, and the short distances from the deposits to the Polish-Slovak state border.

Acknowledgements. We sincerely thank both Reviewers for their remarks and comments.

This research was supported in part by Grant No. 11.11.140.319 of the AGH University of Science and Technology, Faculty of Geology, Geophysics and Environmental Protection, Kraków, Poland.

\section{References}

Adamcová, R., Frankovská, J. \& Durmeková, T. (2009). Engineering geological clay research for a radioactive waste repository in Slovakia. Acta Geologica Slovaca, 1, 71-82.

Adamcová, R., Suraba, V., Krajňák, A., Rosskopfová, O. \& Galamboš, M. (2014). First shrinkage parameters of Slovak bentonites considered for engineered barriers in the deep geological repository of high-level radioactive waste and spent nuclear fuel. Journal of Radioanalytical and Nuclear Chemistry, 302, 737-743. DOI: 10.1007/s10967-014-3292-X.

Andrejkovičová, S., Madejová, J., Czímerová, A., Galko, I., Dohrmann, R. \& Komadel, P. (2006). Mineralogy and chemistry of Fe-rich bentonite from the Lieskovec deposit (Central Slovakia). Geologica Carpathica, 57, 371378.

Andrejkovičová, S., Janotka, I. \& Komadel, P. (2008). Evaluation of geotechnical properties of bentonite from Lieskovec deposit, Slovakia. Applied Clay Science 38, 297-303. DOI:10.1016/j.clay.2007.04.004.

Arbaoui, F. \& Boucherit, M. N. (2014). Comparison of two Algerian bentonites: Physico-chemical and retention capacity study. Applied Clay Science, 91-92, 6-11. DOI: 10.1016/j.clay.2014.02.001.

Arslan, M., Abdioğlu, E. \& Kadir, S. (2010). Mineralogy, geochemistry and origin of bentonite in Upper Cretaceous pyroclastic units of the Tirebolu area, Giresun, Northeast Turkey. Clays and Clay Minerals, 58, 120-141. DOI: 10.1346/CCMN.2010.0580112.

Christidis, G.E. (2013). Assessment of Industrial Clays. Pp. 425-444 in: Handbook of Clay Science. Part B: Techniques and Applications (F. Bergaya \& G. Lagaly, editors). Elsevier, Amsterdam, Oxford.

Christidis, G. \& Dunham, A.C. (1993). Compositional variations in smectites. Part I: Alteration of intermediate volcanic rocks, case study from Milos Island, Greece. Clay Minerals, 28, 255-273.

Christidis, G. \& Dunham, A.C. (1997). Compositional variations in smectites. Part II: Alteration of acidic precursors, case study from Milos Island, Greece. Clay Minerals, 32, 253-270.

Čičel, B., Komadel, P., Bednarikova, E. \& Madejová, J. (1992). Mineralogical composition and distribution of Si, $\mathrm{AI}, \mathrm{Fe}, \mathrm{Mg}$ and $\mathrm{Ca}$ in the fine fraction of some Czech and Slovak bentonites. Geologica Carpathica - Clays, 43, 3-7. 
Deliová, J., Adamcová, R., Ottner, F. \& Wriessnig, K. (2015). Porovnanie bentonitu BKT s bentonitom K45 z ložiska Kopernica. Študentská vedecká konferencia PriF UK 2015. Zborník recenzovaných príspevkov. Bratislava: Univerzita Komenského, 1209-1214. [in Slovak]

Galamboš, M., Rosskopfová, O., Kufčáková, J. \& Rajec, P. (2011). Utilization of Slovak bentonites in deposition of high-level radioactive waste and spent nuclear fuel. Journal of Radioanalytical and Nuclear Chemistry, 288, 765-777. DOI: 10.1007/s10967-011-0987-0

Górniak, K., Szydłak, T., Gaweł, A., Klimek, A., Tomczyk, A., Sulikowski, B., Olejniczak, Z., Motyka, J., Serwicka, E.M., Bahranowski, K. (2016). Commercial bentonite from the Kopernica deposit (Tertiary, Slovakia): a petrographic and mineralogical approach. Clay Minerals, 51, 97-122. DOI: 10.1180/claymin.2016.051.1.09

Górniak, K., Szydłak, T., Gaweł, A., Klimek, A., Tomczyk, A., Motyka, J., Bahranowski, K. (2017). Smectite-, silica- and zeolites-bearing raw materials (Hliník nad Hronom bentonite, Slovakia) - A new approach using integrated petrographic and mineralogical studies. Applied Clay Science, 141, 180-191. DOI: 10.1016/j.clay.2017.02.032

Harvey, C.C. \& Lagaly, G. (2013). Industrial Applications. Pp. 451-486 in: Handbook of Clay Science. Part B: Techniques and Applications (F. Bergaya \& G. Lagaly, editors). Elsevier, Amsterdam, Oxford.

Konečny, V., Lexa, J., Šimon, L. \& Dublan, L. (2001). The Neogene volcanism in central Slovakia. Mineralia Slovaca, 33, 159-179.

Koutsopoulou, E., Christidis, G.E. \& Marantos, I. (2016). Mineralogy, geochemistry and physical properties of bentonites from the Western Thrace Region and the islands of Samos and Chios, East Aegean, Greece. Clay Minerals, 51, 563-588. DOI: 10.1180/claymin.2016.051.4.03.

Kraus, I., Čičel, B. \& Machajdik, D. (1982). Origin and genesis of the clays resulting from alteration of rhyolite volcanic rocks in Central Slovakia. Geologica Carpathica, 33, 269-275.

Kraus, I., Hroncová, Z., Horský, S. \& Mihalič, A. (1989). Ložiská a výskyty bentonitov SSR. Deposits and occurrence of bentonite in the Slovak Socialist Republic. Mineralia Slovaca, 21, 525-531.

Kraus, I., Šamajová, E., Šucha, V., Lexa, J. \& Hroncová, Z. (1994). Diagenetic and hydrothermal alterations of volcanic rocks into clay minerals and zeolites (Kremnické Vrchy Mts., the Western Carpathians). Geologica Carpathica, 45, 3, 151-158.

Lewicka, E. \& Wyszomirski, P. (2008). Bentonity słowackie i ich wykorzystanie w polskim przemyśle. Gospodarka Surowcami Mineralnymi - Mineral Resources Management, 24, 235-250. [in Polish]

Madejová, J., Komadel, P., Čičel, B. (1992). Infrared spectra of some Czech and Slovak smectites and their correlation with structural formulas. Geologica Carpathica, Series Clays, 43, 9-12.

Panna, W., Wyszomirski, P. \& Motyka, J. (2012). Możliwości wykorzystania wybranych surowców smektytowych jako materiałów dla celów hydroizolacyjnych. Zeszyty Naukowe IGSMiE PAN, 83, 131-145. [in Polish]

Record of Mining Areas - Evidencia Dobyvacich Priestorov (2016). Obvodný banský úrad v Banskej Bystrici (stav k 30.9.2016). http://www.hbu.sk/sk/Dobyvacie-priestory/Banska-Bystrica.alej

Reynolds, R.C. \& Hower, J. (1970). The nature of interlayering in mixed-layer illite-montmorillonites. Clays and Clay Minerals, 18, 25-36.

Slovak Minerals Yearbook (2014). Compiled by P. Baláž \& D. Kúšik. Bentonite, 61-62. State Geological Institute of Dionyz Stur, Spišská Nová Ves - Bratislava.

Sohling, U., Ruf, F., Schurz, K., Emmerich, K., Steudel, A., Schuhmann, R., Weidler, P.G., Ralla, K., Riechers, D., Kasper, C. \& Scheper, T. (2009). Natural mixture of silica and smectite as a new clayey material in industrial application. Clay Minerals, 44, 525-537. DOI: 10.1180/claymin2009.044.4.525.

Stríček, I., Šucha, V., Uhlík, P. \& Madejová, J. (2006). Zvetrávanie smektitu na ložiskách bentonitu. Mineralia Slovaca, 38, 337-342. [in Slovak]

Stríček, I., Baliak, F. \& Uhlík, P. (2011). Mock-up Experiment for Bentonite Barrier Testing. Górnictwo $i$ Geoinżynieria, 35, 2, 543-548.

Šamajová, E., Kraus, I. \& Lajčákova, A. (1992). Diagenetic alteration of Miocene acidic vitric tuffs of the Jástraba Formation (Kremnické Vrchy Mts., Western Carpathians). Geologica Carpathica-Clays, 1, 27-30.

Šucha, V., Galko, I., Madejová, J. \& Kraus, I. (1996). Mineralogical and crystallochemical characteristic of bentonite from Zvolenská Slatina region. Mineralia Slovaca, 28, 129-134.

Šucha, V. \& Kraus, I. (1999). Natural microporous materials of Central Slovakia. In: Misaelides P., Macášek F., Pinnavaia T.J. \& Colella C (eds.). Natural microporous materials in environmental technology. NATO Science Series. Series E: Applied Sciences, Kluwer Academic Publishers, 362, 101-107. 
Uhlík, P., Jánošík, M., Kraus, I., Pentrák, M. \& Čaplovičová, M. (2012). Characterisation of bentonite from Hliník nad Hronom deposit (Jastrabá Formation of the Štiavnica stratovolcano, Western Carpathians) Acta Geologica Slovaca, 4, 125-137. [in Slovak with English summary]

Wyszomirski, P. \& Lewicka, E. (2005). Bentonity jako uniwersalny surowiec wielu dziedzin przemysłu. Gospodarka Surowcami Mineralnymi-Mineral Resources Management, 21, 5-19. [in Polish] 